\title{
PENGARUH KUALITAS LAYANAN TERHADAP LOYALITAS PELANGGAN YANG DIMEDIASI OLEH KEPUASAN PELANGGAN (J\&T EXPRESS)
}

\author{
Anggi Nadia Jeni Saputri ${ }^{1}$ \\ Vina Apriani ${ }^{2}$ \\ Ajat Sudrajat ${ }^{3}$ \\ ${ }^{1}$ Fakultas Ekonomi, Universitas Singaperbangsa Karawang \\ Email : 1710631020011@student.unsika.ac.id \\ ${ }^{2}$ Fakultas Ekonomi, Universitas Singaperbangsa Karawang \\ Email : 1710631020022@student.unsika.ac.id \\ ${ }^{3}$ Fakultas Ekonomi, Universitas Singaperbangsa Karawang \\ Email : Ajat.sudrajat@fe.unsika.ac.id
}

\begin{abstract}
Abstrak
Penelitian ini bertujuan untuk menguji dan menganalisis tentang Pengaruh Kualitas Layanan Terhadap Loyalitas Pelanggan yang di Mediasi Oleh Kepuasan Pelanggan (Study Kasus Pada Pengguna Jasa Ekspedisi J\&T Express Cabang Karawang) dengan populasi penelitian yaitu semua pengguna J\&T Express Cabang Karawang pada bulan September tahun 2019. Dalam penelitian ini diambil 100 responden sebagai sampel. Penentuan sampel menggunakan sampling insidental dengan kriteria responden ialah pengguna J\&T Express Cabang Karawang. Alat analisis yang digunakan dalam penelitian ini adalah analisis kuantitatif (uji validitas dan reliabilitas), analisis regresi linier berganda, uji asumsi klasik (mulitkolinieritas, heterosdastisitas dan normalitas), uji t dan koefisien determinasi. Hasil penelitian ini menjelaskan bahwa kualitas pelayanan berpengaruh signifikan terhadap kepuasan pelanggan, kepuasan pelanggan berpengaruh signifikan terhadap loyalitas pelanggan, sedangkan kualitas pelayanan tidak berpengaruh signifikan terhadap loyalitas pelanggan.
\end{abstract}

Kata Kunci : Kualitas Layanan, Kepuasan Pelanggan, Loyalitas Pelanggan

\section{PENDAHULUAN}

Dalam era globalisasi saat ini perkembangan dunia bisnis berkembang dengan sangat pesat, salah satunya adalah bisnis dibidang Jasa Pengiriman atau Bisnis Ekspedisi. Bisnis ekspedisi merupakan suatu usaha yang bergerak di bidang layanan pengiriman barang antar kota, antar propinsi, antar pulau, bahkan antar negera. Layanan ekspedisi meliputi pengiriman surat dan dokumen berharga, pengiriman barang dengan kapasitas kecil hingga besar.

Karawang termasuk salah satu kota industri yang potensial untuk berbisnis dalam segala bidang, salah satunya adalah bisnis dibidang ekspedisi yang sudah berkembang sangat pesat. Beberapa perusahaan ekspedisi sudah tersebar, salah satunya adalah J\&T Express Karawang. J\&T merupakan perusahaan layanan pengiriman ekspress berdasarkan pengembangan dari sistem IT, J\&T melayani pengiriman keseluruh kota, domestik dan internasional termasuk bisnis e-commerce. Menyediakan layanan pengambilan barang dan mengantar barang dengan cepat ke konsumen. Perusahaan J\&T memiliki perkembangan yang cukup pesat tetapi pihak J\&T harus menyadari adanya persaingan dengan layanan ekspedisi lainnya.

Tabel 1

Perusahaan Ekspedisi Terbaik Oleh TOP Brand Indonesia

\begin{tabular}{ccc}
\hline BRAND & TOP BRAND INDONESIA 2019 \\
\hline JNE & $26,4 \%$ & TOP \\
J\&T & $20,3 \%$ & TOP \\
Tiki & $12,6 \%$ & TOP \\
Pos Indonesia & $5,4 \%$ & \\
DHL & $3,8 \%$ &
\end{tabular}

Sumber: https://www.topbrand-award.com/top-brand-index/ 
Berdasarkan data yang bersumber dari TOP BRAND INDONESIA, dapat dilihat bahwa JNE menduduki posisi pertama dan J\&T menduduki posisi kedua. Ketatnya persaingan di bidang jasa ekspedisi mengharuskan J\&T Express Cabang Karawang untuk selalu memberikan pelayanan terbaik agar para pengguna layanan loyal dan tidak berpindah pada jasa ekspedisi lainnya.

Berikut merupakan data hasil pra penelitian mengenai loyalitas pelanggan J\&T di Karawang :

\section{Gambar 1}

Hasil Pra Penelitian Loyalitas Pelanggan Pada J\&T Karawang

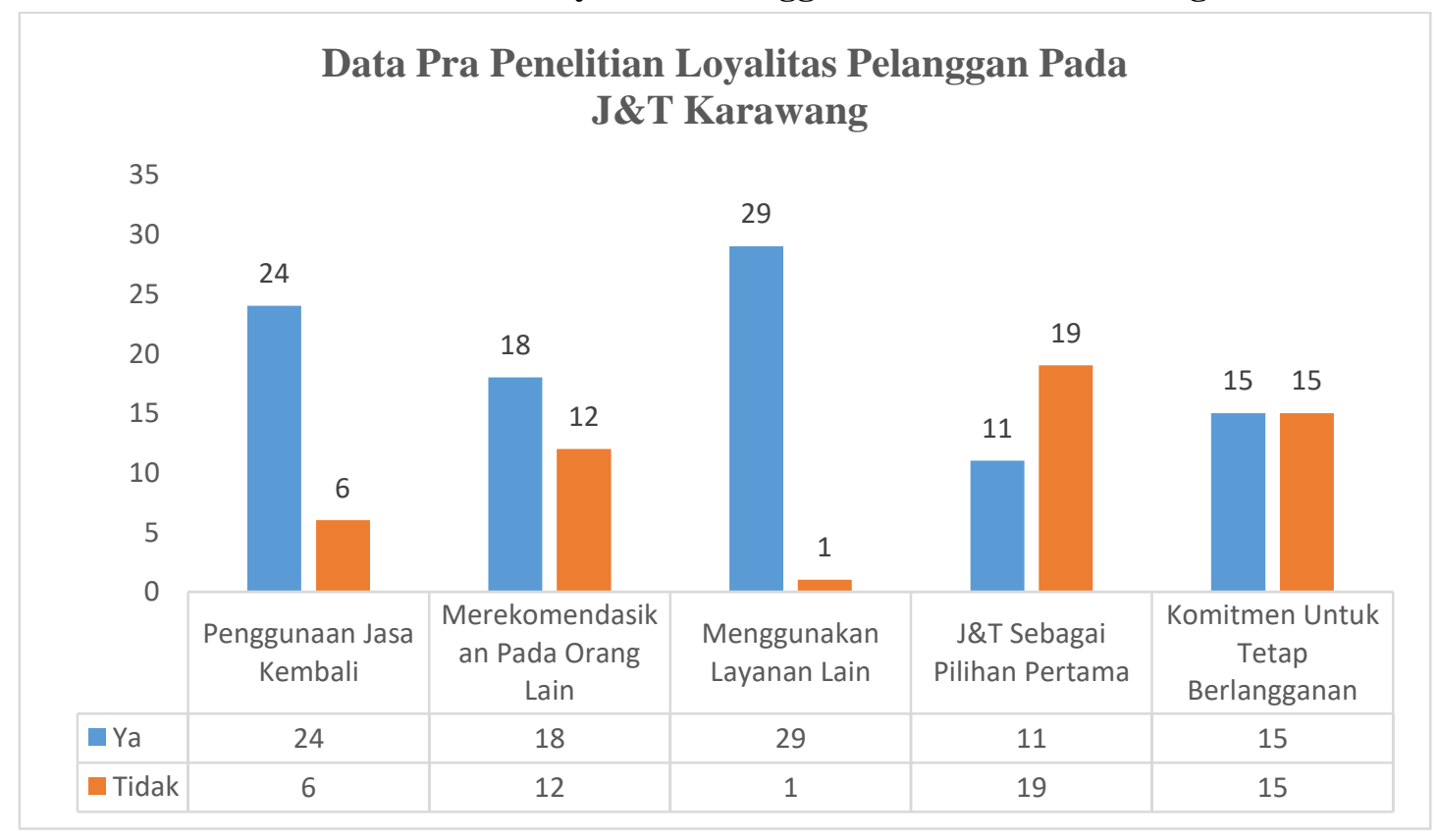

Sumber : Data diolah, 2019

Berdasarkan data diatas, dapat dilihat deskripsi jawaban dari 30 responden mengenai loyalitas pelanggan, yang tertera dalam 5 pertanyaan dapat disimpulkan bahwa 19 responden menyatakan J\&T bukan merupakan pilihan pertama dalam penggunaan jasa ekspedisi, kemudian 29 responden merupakan pengguna jasa ekspedisi lain dan 15 responden menyatakan tidak berkomitmen untuk tetap menggunakan layanan. Jadi berdasarkan data Pra Penelitian, hasil untuk J\&T Karawang harus terus memperbaiki kualitas layanan, menciptakan kepuasan pelanggan agar tercipta loyalitas pelanggan.

Loyalitas pelanggan adalah komitmen pelanggan terhadap suatu merek toko, pemasok, berdasarkan sikap yang sangat positif dan tercermin dalam pembelian ulang yang konsisten, hal tersebut dinyatakan oleh Morais dalam (Sangadji \& Sopiah, 2013).

Uraian tersebut menunjukan bahwa loyalitas pelanggan sangat penting bagi suatu perusahaan produk barang atau jasa untuk meningkatkan keuntungan bagi suatu perusahaan, karena apabila pelanggan loyal terhadap perusahaan maka dipastikan mereka tidak akan berpaling ke produk lain. Salah satu faktor yang mempengaruhi loyalitas pelanggan adalah kualitas layanan, berdasarkan pengalaman yang diperolehnya, pelanggan memiliki kecenderungan untuk membangun nilai-nilai tertentu. Nilai tersebut akan memberikan dampak bagi pelanggan untuk memberikan perbandingan terhadap kompetitor dari kualitas pelayanan yang pernah dirasakannya. Apabila sebuah perusahaan dapat memberikan kualitas pelayanan yang baik, maka diharapkan mampu memenuhi harapan pelanggan.

Sejalan dengan pernyataan Menurut Kotler dalam (Tjiptono, 2018) menyatakan bahwa kualitas pelayanan adalah setiap tindakan atau perbuatan yang dapat ditawarkan. Kualitas layanan harus dimulai dari kebutuhan pelanggan dan berakhir dengan kepuasan pelanggan serta persepsi positif terhadap kualitas pelayanan. Berikut merupakan data hasil pra penelitian mengenai kualitas layanan pada jasa ekspedisi J\&T di Karawang. 
Gambar 2

Hasil Pra Penelitian Kualitas Layanan Pada J\&T Karawang

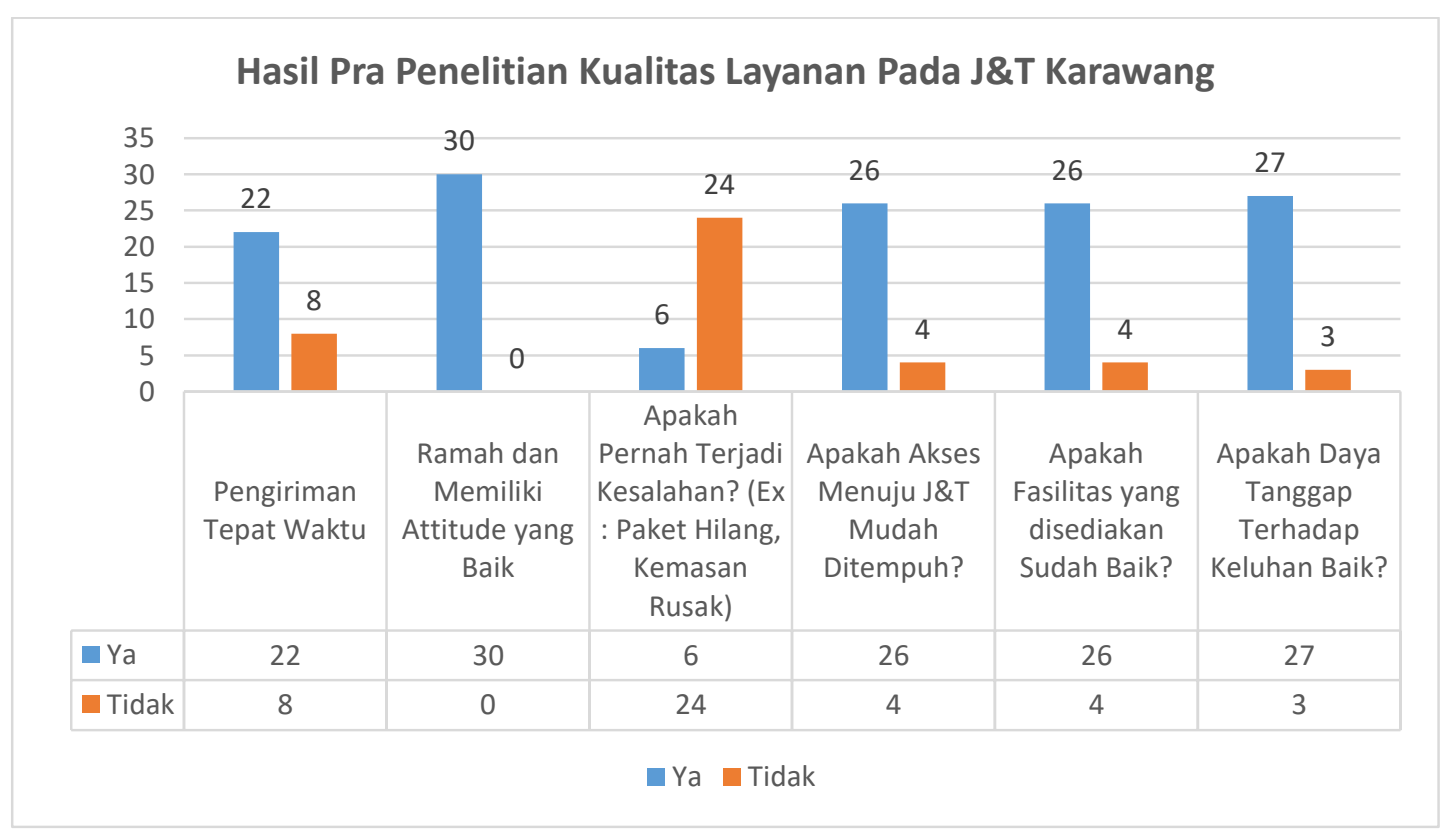

Sumber : Data diolah, 2019

Berdasarkan data diatas, dapat dilihat bahwa deskripsi jawaban dari 30 responden mengenai kualiatas layanan, yang tertera dalam 6 pertanyaan, masih ada responden yang menjawab tidak pada ketepatan waktu pengiriman, pernah mengalami paket hilang/rusak, jarak yang tidak mudah diakses, fasilitas dan daya tanggap dianggap belum baik meski banyak pula yang menjawab sudah baik tetapi hal tersebut harus diperhatikan agar pelanggan merasa puas sehingga perusahaan dapat terus maju dan berkembang.

Faktor lain yang di duga mempengaruhi loyalitas selain kualitas pelayanan adalah kepuasan pelanggan. Berikut merupakan data hasil pra penelitian mengenai Kepuasan Pelanggan pada jasa ekspedisi J\&T di Karawang.

\section{Gambar 3}

Hasil Pra Penelitian Kepuasan Pelanggan Pada J\&T Karawang

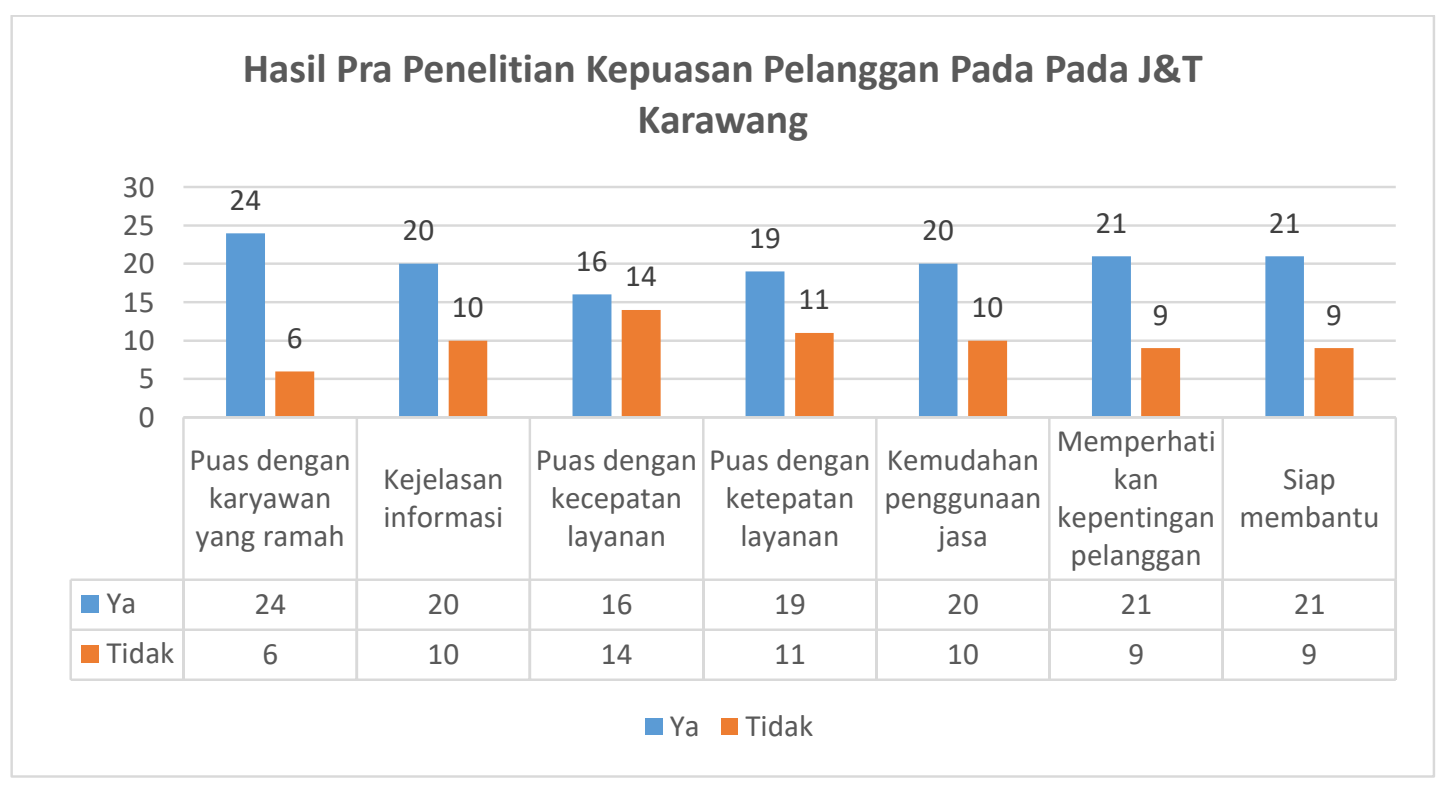

Sumber : Data diolah, 2019 
Berdasarkan data diatas, dapat dilihat bahwa deskripsi jawaban dari 30 responden mengenai kepuasan pelanggan, yang tertera dalam 7 pertanyaan, masih ada responden yang menjawab tidak puas dengan kecepatan layanan, ketepatan layanan, kemudahan penggunaan jasa, dan kelejasan informasi. Meski banyak pula yang menjawab sudah baik tetapi hal tersebut harus diperhatikan agar perusahaan dapat terus maju dan berkembang.

Penelitian yang akan diteliti ini sebelumnya telah dilakukan oleh Aris Irnandha (2016), menyatakan bahwa dalam hasil penelitiannya terdapat pengaruh yang signifikan antara kualitas pelayanan terhadap loyalitas pelanggan yang di mediasi oleh kepuasan pelanggan pengiriman jalur darat (Studi Kasus Kepuasan Pelanggan JNE Cabang Hijrah Segan Yogyakarta). Sejalan dengan penelitian yang telah dilakukannya tersebut peneliti memilih untuk meneliti Perusahaan Jasa Ekspedisi J\&T Ekspress cabang Karawang.

Berdasarkan uraian pada latar belakang yang telah dipaparkan. Penulis tertarik untuk melakukan penelitian yang berfokus pada Pengaruh Kualitas Layanan Terhadap Loyalitas Pelanggan yang di mediasi Oleh Kepuasan Pelanggan Pada Pengguna Jasa Ekspedisi J\&T Express Cabang Karawang. Penelitian ini bertujuan menganalisis besarnya pengaruh kualitas layanan terhadap loyalitas pelanggan yang di mediasi oleh kepuasan pelanggan (study kasus pada pengguna jasa ekspedisi J\&T Express Cabang Karawang).

\section{KAJIAN PUSTAKA Kualitas Layanan}

Menurut Kotler dalam (Tjiptono, 2018) menyatakan bahwa kualitas pelayanan adalah setiap tindakan atau perbuatan yang dapat ditawarkan. Menurut Parasuraman, Zeithami, dan Berry dalam (Tjiptono \& Chandra, 2016), menyatakan bahwa terdapat lima dimensi utama yang disusun sesuai urutan tingkat kepentingan relatifnya sebagai berikut:

1. Relialibilitas (reliability), berkaitan dengan kemampuan perusahaan untuk menyampaikan layanan yang dijanjikan secara akurat sejak pertama kali.

2. Daya Tanggap (respondlveness), berkenaan deng kesediaan dan kemapuan penyedia layanan untuk membantu para pelanggan dan merespon permintaan mereka dengan segera.

3. Jaminan (assurance), berkenaan dengan pengetahuan dan kesopanan karyawan serta kemampuan mereka dalam menumbuhkan rasa percaya (trust) dan keyakinan pelanggan (confidence).

4. Empati (empathy), berarti bahwa perusahaan memahami masalah para pelanggannya dan bertindak demi kepentingan pelanggan, serta memberikan perhatian personal kepada para pelanggan dan memiliki jam operasi yang nyaman.

5. Bukti fisik (tangible), berkenaan dengan penampilan fisik fasilitas layanan, peralatan/perlengkapan, sumber daya manusia dan materi komunikasi perusahaan.

\section{Kepuasan Pelanggan}

Menurut Kotler dan Keller dalam (Juni, 2017), menyatakan bahwa kepuasan pelanggan adalah perasaan senang atau kecewa seseorang yang muncul setelah membandingkan antara kinerja (hasil) produk yang diperkirakan terhadap kinerja (atau hasil) yang diharapkan. Dalam mengevaluasi kepuasan terhadap suatu jasa, konsumen umumnya mengacu pada berbagai faktor tau dimensi berikut Parasuraman et, al., dalam (Tjiptono, 2018).

1. Bukti Langsung (tangibles), meliputi fasilitas fisik, perlengkapan, pegawai, dan sarana komunikasi.

2. Keandalan (reliability) yakni kemampuan memberikan pelayanan yang dijanjikan dengan segera, akurat dan memuaskan.

3. Daya tanggap (responsiveness), yaitu keinginan para staf dan karyawan untuk $m$ ebantu para pelanggan dan memberikan pelayanan dengan tanggap.

4. Jamian (assurance), mencakup pengetahuan, kemampuan, kesopanan dan sifat dapat dipercaya yang dimiliki para staf, bebas dari bahaya, resiko atau keragu-raguan.

5. Empati (empathy), meliputi kemudahan dalam melakukan hubungan, komunikasi yang baik, perhatian pribadi, dan memahami kebutuhan para pelanggan. 


\section{Loyalitas Pelanggan}

Tjiptono dan Chandra dalam (Juni, 2017) menyatakan bahwa loyalitas pelanggan adalah komitmen pelanggan terhadap suatu produk atau jasa yang tercermin dari sikap (attitude) yang sangat positif dan wujud perilaku (behavior) pembelian ulang yang dilakukan oleh pelanggan tersebut secara konsisten dalam jangka waktu yang lama. Menurut Griffin dalam (Darwin \& Yohanes, 2014) ada empat atribut dalam loyalitas pelanggan, yaitu:

1. Makes regular purchase, melakukan pembelian secara berulang dalam periode tertentu.

2. Purchase across product and service line, pelanggan yang loyal tidak hanya membeli satu macam produk saja melainkan membeli lini produk dan jasa lain pada badan usaha yang sama.

3. Refers other, merekomendasikan pengalaman mengenai produk dan jasa kepada rekan atau pelanggan yang lainagar tidak membeli produk dan jasa dari badan usaha yang lain.

\section{METODE PENELITIAN}

Jenis penelitian yang akan dilakukan kali ini adalah penelitian kuantitatif dengan metode deskriptif dan verifikatif. Populasi dalam penelitian ini adalah semua pengguna J\&T Express Cabang Karawang pada bulan September tahun 2019 yang jumlahnya 16.926 pengguna (Sumber: Supervisor J\&T Ekspress Cabang Karawang). Berdasarkan populasi sebanyak 16.926 pengguna J\&T Cabang Karawang pada bulan September 2019. Maka diketahui jumlah sampel menggunakan rumus dari Slovin dengan menggunakan taraf kesalahan 10\% didapatkan sampel sebanyak 99,994 dibulatkan menjadi 100 pengguna.Teknik sampling yang digunakan dalam penelitian ini adalah dengan menggunakan sampling insidental.

Pada penelitian ini penulis menggunakan teknik pengumpulan data dengan kuesioner. Untuk memperoleh data tentang pengaruh kualitas layanan terhadap loyalitas pelanggan yang dimediasi oleh kepuasan pelanggan dibuat instrumen penelitian dalam bentuk skala likert. Kemudian instrumen penelitian tersebut di uji validitas dan reliabilitas. Secara sistematis, uji validitas ini menggunakan kolerasi sederhana (simple correlation) dari pearson. Sedangkan dalam pengambilan keputusan reliabitias, suatu instrumen dikatakan reliable bila koefisien reliabilitas minimal 0,600 dan menguji reliabel dengan menggunakan SPSS (Sugiyono, 2017). Uji normalitas menggunakan Metode Kolmogorov - Smirnov. Teknik analisis data yang dipergunakan dalam penelitian ini adalah dengan menggunakan analisis jalur.

\section{HASIL PENELITIIAN Hasil Uji Validitas}

Uji validitas merupakan suatu ukuran yang menunjukan tingkat kevalidan suatu instrumen dalam penelitian. Dari data yang diperoleh oleh peneliti hasil dari menyebarkan kuesioner kepada sampel yang jumlahnya sebanyak 30 responden, didapatkan hasil analisis validitas yang dibantu dengan menggunakan SPSS 16.0, penulis dapat mengetahui bahwa kuesioner tersebut valid atau tidak valid dengan membandingkan nilai $\mathrm{r}(\mathrm{r}>0,300$ (valid) atau $\mathrm{r}<0,300$ (tidak valid)). Berdasarkan perhitungan nilai $r$ hitung dari setiap butir-butir pertanyaan per variabel yaitu: variabel kualitas layanan sebanyak 12 butir pertanyaan, variabel kepuasan pelanggan sebanyak 12 butir pertanyaan, dan variabel loyalitas pelanggan sebanyak 9 butir pertanyaan,didapatkan hasil valid dengan nilai $r$ hitung lebih besar dari $r$ kritis (0.30).

\section{Hasil Uji Reliabilitas}

Untuk mengetahui reliabilitas setiap variable dalam penelitian ini, peneliti menggunakan alat bantu SPSS 16.0. Dengan menggunakan alat bantu SPSS, peneliti dapat mengetahui bahwa kuesioner tersebut reliable atau tidak, reliabel yang artinya $r>0,600$ atau $r<0,600$.

Adapun hasil dari uji reliabilitas variabel dalam penelitian ini adalah sebagai berikut :

\section{Tabel 2 \\ Hasil Uji Reliabilitas}

\begin{tabular}{lrcc}
\hline \multicolumn{1}{c}{ Variabel } & r Hitung & r Kritis & Kriteria \\
\hline Kualitas Layanan $(\mathrm{X})$ & 0,936 & 0,600 & Reliabel \\
Kepuasan Pelanggan $(\mathrm{Y})$ & 0,932 & 0,600 & Reliabel \\
Loyalitas Pelanggan $(\mathrm{Z})$ & 0,911 & 0,600 & Reliabel \\
\hline
\end{tabular}


Berdasarkan Tabel 2, dapat diketahui bahwa, nilai alpha cronbach (a) untuk setiap variabel lebih besar dari 0,600, sehingga variabel Kualitas Layanan (X), Kepuasan Pelanggan (Y), dan variabel Loyalitas Pelanggan (Z) dapat dinyatakan reliabel.

\section{Uji Normalitas}

Uji normalitas digunakan untuk mengetahui apakah suatu data mengikuti sebaran normal atau tidak normal dengan menggunakan metode Kolmogorov-Smirnov yang dibantu oleh SPSS 16.0. Dengan ketentuan apabila variabel memiliki a hitung lebih besar dari 0,050 maka variabel tersebut mengikuti distribusi normal.

\begin{tabular}{lccc}
\multicolumn{4}{c}{ Tabel 3 } \\
\\
\multicolumn{1}{c}{ Hasil Uji Normalitas } & \\
& \multicolumn{2}{c}{ Kolmogorov - Smirnov } & \multirow{2}{*}{ Kriteria } \\
& a Hitung & a Kritis & \\
\hline Kualitas Layanan (X) & 0,999 & 0,050 & Distribusi Normal \\
Kepuasan Pelanggan (Y) & 0,947 & 0,050 & Distribusi Normal \\
Loyalitas Pelanggan (Z) & 0,969 & 0,050 & Distribusi Normal \\
\hline
\end{tabular}

Pada Tabel 3, menunjukkan bahwa semua variabel mengikuti sebaran data distribusi normal karena nilai signifikan a hitung semua variabel dalam penelitian ini lebih dari 0,050.

\section{PEMBAHASAN}

\section{Pengaruh Kualitas Layanan Terhadap Kepuasan Pelanggan J\&T Express Cabang Karawang}

Hipotesis pertama dalam penelitian ini adalah terdapat pengaruh yang signifikan antara kualitas layanan terhadap kepuasan pelanggan. Berdasarkan hasil analisis yang diperoleh nilai signifikan kualitas pelayanan sebesar 0,000. Nilai ini lebih kecil dari 0,10. Ini berarti $\mathrm{H}_{0}$ ditolak dan $\mathrm{H}_{\mathrm{a}}$ diterima oleh sebab itu dapat disimpulkan bahwa kualitas pelayanan berpengaruh secara signifikan terhadap kepuasan pelanggan J\&T Express Cabang Karawang.

Berdasarkan hasil penelitian menunjukkan bahwa variabel kualitas layanan pada J\&T Cabang Karawang diperoleh total skor sebesar 4.681 dengan nilai rata-rata skor sebesar 390 berada pada rentang skala 340 - 420 dengan kriteria setuju. Terdapat 12 indikator kualitas layanan pada J\&T Cabang Karawang yaitu ketepatan layanan, kecepatan layanan, layanan gratis jemput paket, daya tanggap keluhan, karyawan cekatan, keamanan paket terjamin, jaminan ganti rugi, keramahan karyawan, kemudahan dalam menyampaikan kritik dan saran, fasilitas dan sarana memadai, kerapihan dan kebersihan ruangan,penampilan karyawan. Semua indikator tersebut berada pada kriteria setuju, artinya secara umum J\&T Cabang Karawang sudah mampu memberikan kualitas layanan yang sesuai dengan harapan dan kebutuhan pengguna layanan. Hal tersebut sesuai dengan (Sembiring, 2014) mengatakan bahwa kualitas pelayanan yaitu seberapa jauh perbedaan antara kenyataan dan harapan pelanggan atas pelayanan yang mereka terima.

Penelitian ini menunjukan bahwa total pengaruh kualitas layanan terhadap kepuasan pelanggan sebesar 0,858atau 85,5\%. Artinya bahwa jika suatu kualitas layanan meningkat maka kepuasan pelanggan juga akan meningkat. Hal tersebut sejalan dengan pernyataan Zeithaml, dalam (Darwin \& Yohanes, 2014), dimana kepuasan pelanggan dipengaruhi oleh persepsi pelanggan atas kualitas layanan. Apabila persepsi pelanggan atas kualitas layanan tinggi, maka kepuasan pelanggan juga akan tinggi, demikian juga sebaliknya. Penelitian ini mendukung penelitian sebelumnya yang telah dilakukan oleh Mila Rostiana (2018) bahwa kualitas layanan berpengaruh positif terhadap kepuasan pelanggan.

\section{Pengaruh Kepuasan Pelanggan Terhadap Loyalitas Pelanggan J\&T Express Cabang Karawang}

Hipotesis kedua dalam penelitian ini adalah terdapat pengaruh yang signifikan antara kepuasan pelanggan terhadap loyalitas pelanggan. berdasarkan hasil analisis yang diperoleh nilai signifikan kepuasan pelanggan sebesar 0,000. Nilai ini lebih kecil dari 0,10. Ini berarti $\mathrm{H}_{0}$ ditolak dan $\mathrm{H}_{\mathrm{a}}$ diterima oleh sebab itu dapat disimpulkan bahwa kepuasan pelanggan berpengaruh secara signifikan terhadap loyalitas pelanggan J\&T Express Cabang Karawang. 
Berdasarkan hasil penelitian menunjukkan bahwa variabel kepuasan pelanggan pada J\&T Cabang Karawang diperoleh total skor sebesar 4.681 dengan nilai rata-rata skor sebesar 390 berada pada rentang skala 340 - 420 dengan kriteria setuju. Terdapat 12 indikator kualitas layanan pada J\&T Cabang Karawang yaitu puas dengan fasilitas, puas dengan kerapihan dan kebersihan ruangan, puas dengan penampilan karyawan, puas dengan ketepatan layanan, puas dengan kecepatan layanan, puas dengan layanan gratis jemput paket, puas dengan daya tanggap yang baik, puas dengan karyawan yang cekatan, puas dengan jaminan keamanan paket, puas dengan adanya jaminan ganti rugi, puas dengan keramahan karyawan, puas dengan kemudahan penyampaian kritik dan saran. Semua indikator tersebut berada pada kriteria setuju, artinya pihak J\&T Cabang Karawang sudah berupaya untuk bisa memuaskan kebutuhan dan keinginan para pengguna layanan. Hal tersebut sejalan dengan pernyataan Schnaars (Tjiptono, 2008), "Pada dasarnya tujuan dari sebuah bisnis adalah menciptakan para pelanggan yang puas." Menurut (Tjiptono, 2018), terciptanya kepuasan pelanggan dapat memberikan sejumlah manfaat spesifik, di antaranya: (1) berdampak positif terhadap loyalitas pelanggan; (2) berpotensi menjadi sumber pendapatan masa depan, terutama melalui pembelian ulang, cross-selling, dan up-selling; (3) menekan biaya transaksi penjualan, dan layanan pelanggan; (4) menekan volatilitas dan resiko berkenaan dengan prediksi aliran kas masa depan; (5) meningkatkan toleransi harga, terutama kesediaan pelanggan untuk membayar harga premium dan pelanggan cenderung tidak mudah tergoda untuk beralih pemasok; (6) menumbuhkan rekomendasi positif; (7) pelanggan cenderung lebih reseptif terhadap product-line extensions, brand ekstensions, dan new add-on services yang ditawarkan perusahaan, serta (8) meningkatkan barganing power relatif perusahaan terhadap jaringan pemasok, mitra bisnis, dan saluran distribusi.

Penelitian ini menunjukan bahwa total pengaruh Kepuasan Pelanggan terhadap Loyalitas Pelanggan sebesar 0,644 atau 64,4\%. Artinya kepuasan pelanggan menentukan loyalitas pelanggan. Hal tersebut terbukti sama dengan penelitian (Rostiana, 2018), bahwa terdapat pengaruh signifikan antara kepuasan pelanggan terhadap loyalitas pelanggan. Menurut Kotler dan Armstrong (Kotler \& Amstrong, 2018) menyatakan bahwa membangun loyalitas pelanggan dapat dilakukan melalui kepuasan pelanggan.

\section{Pengaruh Kualitas Layanan Terhadap Variabel Loyalitas Pelanggan J\&T Express Cabang Karawang}

Hipotesis pertama dalam penelitian ini adalah terdapat pengaruh yang signifikan antara kualitas layanan terhadap loyalitas pelanggan. Berdasarkan hasil analisis yang diperoleh nilai signifikan kualitas layanan sebesar 0,375. Nilai ini lebih besar dari 0,10 . Ini berarti $\mathrm{H}_{0}$ diterima oleh sebab itu dapat disimpulkan bahwa Dengan demikian dapat disimpulkan bahwa kualitas layanan tidak berpengaruh signifikan terhadap loyalitas pelanggan.

Berdasarkan hasil penelitian menunjukkan bahwa variabel loyalitas pelanggan pada J\&T Cabang Karawang diperoleh total skor sebesar 3.355 dengan nilai rata-rata skor sebesar 372,8 berada pada rentang skala 340 - 420 dengan kriteria setuju. Terdapat 9 indikator loyalitas pelanggan pada J\&T Cabang Karawang, terdapat 8 pengukuran indikator berada pada kriteria setuju yaitu Bersedia Menggunakan Jasa Ekspedisi J\&T Setiap Mengirim Barang, Memilih Jasa Ekspedisi J\&T Setiap Memesan Barang, Menggunakan Layanan J\&T Untuk Pengiriman Dalam dan Luar Kota, Bersedia Menggunakan Layanan Reguler Cepat Untuk Barang-Barang Urgent, Merekomendasikan J\&T Ekspress Pada Keluarga dan Teman, Membicarakan Hal Positif Mengenai J\&T Ekspress, Mempertimbangkan J\&T Sebagai Pilihan Pertama, Akan Tetap Loyal Pada J\&T Karawang. Artinya bahwa perusahaan telah berusaha memberikan yang terbaik untuk menciptakan loyalitas pelanggan. Hal tersebut sejalan dengan pernyataan Griffin dalam (Sembiring, 2014).

Karakterisitik dari pelanggan yang loyal menurut antara lain: 1) Melakukan pembelian secara teratur; 2) Membeli diluar lini produk atau jasa; 3) Menunjukan kekebalan dari tarikan persaingan tidak terpengaruhi oleh tarikan persaingan produk sejenis lainnya; 4) Menolak produk lain; 5) Merekomendasikan kepada orang lain. Namun terdapat satu pengukuran indikator yang berada pada kriteria kurang setuju yaitu Tidak Akan Berpindah Pada Jasa Pengiriman Lain. Artinya bahwa masih ada pelanggan yang belum loyal, sehingga pelanggan dengan mudah beralih pada pesaing sehingga dibutuhkan strategi untuk membangun dan mempertahankan loyalitas pelanggan. Menurut Kotler dalam (Sembiring, 2014), loyalitas adalah sebagai komitmen yang dipegang secara mendalam untuk 
membeli atau mendukung kembali produk atau jasa yang disukai dimasa depan meski pengaruh situasi dan usaha pemasaran yang menyebabkan pelanggan beralih.

Penelitian ini menunjukan bahwa, diperoleh total pengaruh kualitas layanan terhadap loyalitas pelanggan sebesar 0,118 atau 11,8\%. Dengan demikian hasil penelitian ini menolak terhadap penelitian terdahulu yang dilakukan oleh Mila Rostiani (2018), yang menyatakan bahwa hubunga kualitas layanan dan loyalitas pelanggan mempunyai tingkat hubungan yang kuat sebesar 0,661 atau $66,1 \%$. Sebagaimana dikatakan Caruana dalam (Clara Gadelia, 2015) kualitas pelayanan merupakan salah satu faktor yang mempengaruhi loyal tidaknya seorang konsumen terhadap perusahaan kita.

\section{Pengaruh Simultan Kualitas Layanan Terhadap Loyalitas Pelanggan yang di Mediasi Oleh Kepuasan Pelanggan}

Pengaruh simultan kualitas layanan terhadap loyalitas pelanggan yang dimediasi oleh kepuasan pelanggan, dengan kriteria uji sig. $(0,000)<\alpha(0,10)$ dan $\mathrm{f}_{\text {hitung }}(61,324)$ dan $>\mathrm{f}_{\text {tabel }}(2,36)$ artinya $\mathrm{H}_{0}$ ditolak. Total pengaruh kualitas layanan dan kepuasan pelanggan terhadap loyalitas pelanggan sebesar 0,558 atau $55,8 \%$. Hal ini menunjukan bahwa adanya pengaruh kualitas layanan terhadap loyalitas pelanggan yang dimediasi oleh kepuasan pelanggan sebesar 55,8\%. Sedangkan sisanya 44,2\% merupakan kontribusi variabel lain $(\varepsilon)$ yang tidak diteliti dalam penelitian ini. Dengan demikian hasil penelitian ini menolak terhadap penelitian terdahulu yang dilakukan oleh Aris Irnandha (2016) yang menyatakan tidak ada pengaruh langsung kualitas layanan terhadap loyalitas pelanggan yang dimediasi oleh kepuasan pelanggan, dengan hasil pengaruh tidak langsung 0,0887 dan signifikan pada 0,0024.

\section{KESIMPULAN}

Berdasarkan hasil penelitian dan pembahasan, maka didapat kesimpulan sebagai berikut :

1. Terdapat pengaruh Kualitas Layanan terhadap Kepuasan Pelanggan pada J\&T Cabang Karawang dengan total pengaruh sebesar 0,736 atau $73,6 \%$. Artinya kepuasan pelanggan dipengaruhi oleh persepsi pelanggan atas kualitas layanan (Service Quality). Sesuai dengan pernyataan Irawan (2009) menurutnya kualitas pelayanan dibidang jasa akan membuat pelanggan merasa puas apabila mereka mendapatkan pelayanan yang baik atau sesuai dengan yang mereka harapkan.

2. Terdapat pengaruh Kepuasan Pelanggan terhadap Loyalitas Pelanggan pada J\&T Cabang Karawang dengan total pengaruh sebesar 0,415 atau $41,5 \%$. Hal ini menunjukan kepuasan pelanggan berpengaruh terhadap loyalitas pelanggan pada J\&T Cabang Karawang. Sesuai dengan pernyataan Kotler dan Armstrong (2018:44) bahwa membangun loyalitas pelanggan dapat dilakukan melalui kepuasan pelanggan

3. Terdapat pengaruh yang sangat kecil atau tidak signifikan antara Kualitas Layanan terhadap Loyalitas Pelanggan pada J\&T Cabang Karawang dengan total pengaruh sebesar 0,014 atau 1,4\%. Hal ini menunjukan bahwa kualitas layanan tidak berpengaruh signifikan terhadap loyalitas pelanggan pada J\&T Cabang Karawang.

4. Terdapat pengaruh kualitas layanan terhadap loyalitas pelanggan yang dimediasi oleh kepuasan pelanggan, dengan kriteria uji sig. $(0,000)<\alpha(0,10)$ dan $\mathrm{f}_{\text {hitung }}(61,324)$ dan $>\mathrm{f}_{\text {tabel }}(2,36)$ artinya $\mathrm{H}_{0}$ ditolak. Total pengaruh kualitas layanan dan kepuasan pelanggan terhadap loyalitas pelanggan sebesar 0,558 atau 55,8\%. Hal ini menunjukan bahwa adanya pengaruh kualitas layanan terhadap loyalitas pelanggan yang dimediasi oleh kepuasan pelanggan sebesar 55,8\%. Sedangkan sisanya $44,2 \%$ merupakan kontribusi variabel lain $(\varepsilon)$ yang tidak diteliti dalam penelitian ini. Dengan demikian hasil penelitian ini menolak terhadap penelitian terdahulu yang dilakukan oleh Aris Irnandha (2016) yang menyatakan tidak ada pengaruh langsung kualitas layanan terhadap loyalitas pelanggan yang dimediasi oleh kepuasan pelanggan, dengan hasil pengaruh tidak langsung 0,0887 dan signifikan pada 0,0024 .

\section{SARAN TEORITIS}

Saran teoritis yang dapat peneliti berikan terkait dengan penelitian ini adalah sebagai berikut :

1. Bagi peneliti selanjutnya disarankan agar dapat mempertimbangkan dengan cermat untuk meneruskan penelitian ini, mengingat hasil regresi sederhana menunjukan bahwa variabel kualitas layanan hanya mempunyai pengaruh sebesar 1,4\% terhadap loyalitas pelanggan, dan sisanya 98,6\% dijelaskan oleh variabel lain yang belum diteliti dalam penelitian ini. 
2. Wilayah pengambilan sampel penelitian ini hanya terbatas pada wilayah tertentu, sehingga untuk penelitian selanjutnya diharapkan dapat memperluas wilayah penelitian. Sehingga dapat memperoleh hasil secara representatif dari berbagai wilayah.

3. Bagi peneliti selanjutnya diharapkan meneliti variabel lain yang belum diteliti tetapi berpengaruh terhadap loyalitas pelanggan. Karena selain variabel yang diteliti dalam penelitian ini, masih ada faktor-faktor lainnya yang diduga mempengaruhi loyalitas pelanggan.

\section{SARAN PRAKTIS}

Penelitian ini mempunyai saran implikasi praktis sebagai masukan kepada pihak terkait yaitu :

1. Bagi perusahaan jasa yang diteliti yaitu J\&T Express Cabang Karawang disarankan untuk terus meningkatkan kualitas layanannya terutama dalam memberikan kesempatan para pelanggan menyampaikan kritik dan saran. Hal ini dikarenakan pada variabel Kualitas Layanan terdapat indikator dengan skor terendah yaitu kemudahan dalam menyampaikan kritik dan saran. Hal ini harus dilakukan agar dapat mendorong peningkatan kepuasan pelanggan sehingga tercipta loyalitas pelanggan.

2. Berdasarkan hasil analisis deskriptif pada variabel kepuasan pelanggan, bahwa indikator puas dengan ketepatan layanan mempunyai nilai mean tertinggi diantara indikator lainnya. Sehingga diharapkan J\&T Express Cabang Karawang terus memberikan layanan yang tepat sehingga dapat membuat para pengguna jasa loyal.

\section{REFERENSI}

Clara Gadelia, C. (2015). Pengaruh Kualitas Layanan dan Brand Image terhadap Loyalitas Konsumen dengan Kepuasan Pelanggan Sebagai Variabel Intervening (Studi Kasus Monopole Coffee Lab Surabaya)".

Darwin, S., \& Yohanes. (2014). Analisis Pengaruh Kualitas Layanan Terhadap Loyalitas Pelanggan Dengan Kepuasan dan Kepercayaan Sebagai Variabel Intervening Pada Asuransi Jiwa Manulife Indonesia. Jurnal Pemasaran Petra, 12.

Irnandha, Aris. 2016. "Pengaruh Kualitas Pelayanan Terhadap Loyalitas Pelanggan yang Dimediasi Oleh Kepuasan Pelanggan Pengiriman Jalur Darat (Study Kasus Kepuasan Pelanggan JNE Cabang Hijrah Segan Yogyakarta)". Yogyakarta: Universitas Negeri Yogyakarta.

Juni, D. (2017). Perilaku Konsumen: Dalam Persaingan Bisnis Kontemporer. CV. Alfabeta.

Kotler, P., \& Amstrong, G. (2018). Principal Of Marketing. Pearson.

Rostiana, M. (2018). Pengaruh Kualitas Layanan Terhadap Loyalitas Pelanggan Melalui Kepuasan Pelanggan Sebagai Variabel Intervening (Studi Kasus Pada Pelanggan Mie XP Karawang.

Sangadji, E. M., \& Sopiah. (2013). Perilaku Konsumen (N. WK (ed.); 1st ed.). C.V ANDI OFFSET.

Sembiring, I. J. (2014). Pengaruh Kualitas Layanan dan Kepuasan Pelanggan Terhadap Loyalitas Pelanggan (Studi Kasus Pada Restoran Fast Food Pizza Hut di Jakarta Selatan). Jurnal Administrasi Bisnis, 15, 10.

Sugiyono. (2017). Metode Penelitian Kuantitatif, Kualitatif, dan R\&D. Alfabeta.

Tjiptono, F. (2008). Service Management (2nd ed.). Andi Offset.

Tjiptono, F. (2009). Strategi Pemasaran Jasa (Andi).

Tjiptono, F. (2018). Service Management: Mewujudkan Layanan Prima. Andi Offset.

Tjiptono, F., \& Chandra, G. (2016). Service, Quality \& Satisfaction. Andi.

https://www.topbrand-award.com/top-brand-index/ 